\title{
Cellular and extracellular carbohydrates and lipids from marine bacteria during growth on soluble substrates and hydrocarbons
}

\author{
Madeleine Goutx, Monique Acquaviva, Jean-Claude Bertrand \\ Centre d'Océanologie de Marseille, URA 41, Faculté des Sciences de Luminy, F-13288 Marseille Cedex 9, France
}

\begin{abstract}
The variability of extracellular excretions of 4 marine bacterial strains was investigated during growth on soluble (acetate or lactate) and insoluble (hydrocarbons) substrates. Cellular and extracellular protein, carbohydrate and lipid contents were estimated at the end of exponential growth phase. Emulsifying capacity of the cell-free culture medium was estimated. Lipid classes were characterized by using thin layer chromatography coupled with flame ionization detection. All strains were found to excrete organic compounds in their culture medium whatever the substrate. Carbohydrate and lipid compounds were the main products whereas proteins were excreted in lesser amounts. Nevertheless, the adaptation of the marine strains to insoluble substrate was characterized by enhanced lipid excretions (mainly phospholipids) which correlated well with higher emulsifying activity on this substrate. These excretions represented 8.6 to 156.2 and 4.3 to $101.6 \mu \mathrm{g}$ per $\mathrm{mg}$ bacterial carbon, for carbohydrates and lipids respectively, according to a recent estimate of the bacterial protein to carbon. ratio. These data show that inputs of dissolved organic compounds through bacterial activity could have important consequences on the physico-chemical characteristics of seawater in area where bacterial biomass is concentrated
\end{abstract}

\section{INTRODUCTION}

The ability of bacteria growing on hydrocarbon substrates to produce emulsifying agents, enabling the penetration of this insoluble substrate into cells, is well known (reviewed by Zajic \& Mahomedy 1984, Rosenberg 1986). However, few studies in the context of the marine environment have been performed on this topic. Similar production of emulsifying agents could occur in sea surface microlayers, which are constantly subject to insoluble compound inputs (Hô et al. 1982, Jullien et al. 1982, Burns \& Saliot 1986, Williams et al. $1986)$ and where bacteria are accumulated and very active (Carlucci et al. 1985, Williams et al. 1986, Romano 1988). First evidence of this was presented in experimental studies by Rambeloarisoa et al. (1984) and Goutx et al. (1987), during the growth of marine bacteria on hydrocarbon substrates. Moreover, these studies showed that, in some specific environmental conditions, the amount of bacterial exudates could represent a not insignificant organic carbon input which has to be quantified. Furthermore, bacterial extracellu- lar production appeared as a phenomenon that should be taken into account in the assessment of biological processes influencing the physico-chemical characteristics at the air/sea interface.

The present work was undertaken using other strains of marine bacteria so as to confirm the importance of the production and the nature of the released compounds during growth on hydrocarbon. Several Pseudomonadaceae, which often make up an important part of bacterial biomass at the air/sea interface (Fehon \& Oliver 1979) were selected. Recently, Guerra-Santos et al. (1984) and Reiling et al. (1986) demonstrated that the production of compounds with tensio-active properties occurred in the same way when bacteria had grown on non-hydrocarbon substrate. In the present study, the capability of the selected strains growing on non-hydrocarbon substrates to produce extracellular compounds was therefore investigated. Production of extracellular compounds which have tensio-active properties can provide the medium with emulsifying capacities. This capacity was estimated in our experiments. The chem- 
ical nature of the extracellular compounds was determined by analyzing cells and supernatants for protein, carbohydrates and lipid content.

\section{MATERIALS AND METHODS}

Organisms and growth conditions. Bacterial strains were isolated from various coastal areas of the Mediterranean Sea. Four strains were selected for their ability to degrade hydrocarbons. They were not able to grow on carbohydrate substrates. Alcaligenes sp. PHY 9 and Pseudomonas nautica were identified according to Krieg \& Holt (1984). Strains no. 8 and no. 17 were characterized as Pseudomonadaceae. The mol\% guanine + cytosine of the DNA of these strains were not estimated. They could not therefore be identified as belonging to the genera Pseudomonas or Alteromonas.

Bacteria were grown at $32{ }^{\circ} \mathrm{C}$ in a synthetic mineral salt medium ( $\mathrm{NaCl} 600 \mathrm{mM}$ ) composed of: tris hydroxymethyl amino methane (50 mM), KCl (10 mM), $\mathrm{CaCl}_{2}$ $(10 \mathrm{mM}), \mathrm{NH}_{4} \mathrm{Cl}(70 \mathrm{mM}), \mathrm{MgSO}_{4} \cdot 7 \mathrm{H}_{2} \mathrm{O}(100 \mathrm{mM})$, $\mathrm{NaHPO}_{4}(1 \mathrm{mM})$, and $\mathrm{FeSO}_{4}(0.3 \mathrm{mM})$ at pH 7.5. The carbon sources added to this mineral medium were either 1 to $3 \mathrm{~g} \mathrm{l}^{-1}$ acetate (or lactate) as soluble substrates or 0.7 to $1 \mathrm{~g} \mathrm{l}^{-1}$ tetradecane and eicosane as insoluble substrates. All experiments were performed after growth on rich medium (synthetic seawater supplemented with $0.5 \%$ yeast extract [Difco] and $0.5 \%$ bactopeptone (Mérieux]), followed by growth on preculture in the experimental conditions. Concentrations of substrates were chosen in order to reach comparable amount of protein when harvesting. The whole cultures $(300 \mathrm{ml})$ were harvested at late exponential growth phase when maximal exocellular lipids production occurred (Goutx et al. 1987). Aeration was provided by agitation on a reciprocal shaker (96 rpm). Growth was monitored by following absorbance at $450 \mathrm{~nm}$ with a Shimadzu UV-visible spectrophotometer, or by estimating the protein content using the method of Lowry et al. (1951).

Emulsifying activity of $6000 \times g$ supernatant was measured by using the previously described procedure (Goutx et al. 1987), slightly modified as follows: the reaction system contained $10 \mathrm{ml}$ of supernatant and $0.1 \mathrm{ml}$ of tetradecane. The stability of emulsion over time was measured at $20^{\circ} \mathrm{C}$ (Roy et al. 1979) after mechanical agitation of the reaction system.

Analytical methods. Proteins and carbohydrates were estimated according to the methods of Lowry et al. (1951) and Dubois et al. (1956) respectively. Lipids were extracted according to the method of Bligh \& Dyer (1959). Separation and identification of classes of compounds were performed using thin-layer chromatography coupled with flame ionization detection on a
Iatroscan apparatus TH 10 (Iatron Laboratories, Tokyo), following the procedure described by Goutx et al. (1987) and slightly modified: 2 development steps were added to the entire procedure. Extracellular lipids of hydrocarbon-grown bacteria were analyzed using a first development in hexane. This allowed the residual hydrocarbon to separate from other lipid classes. Polar lipids separation was improved by using a last development in dichloromethane:methanol:water $(5: 4: 1)$ according to Delmas et al. (1984). It separated phospholipids from non-lipid material which remained at the origin. Lipids were identified on the basis of their ability to co-chromatograph with authentic standards purchased from Sigma LTP Corp. Lipids were quantified with reference to calibration curves performed for each class of standard compounds in the range of 0.5 to $20 \mu \mathrm{g}$ (30 $\mathrm{gg}$ for phospholipids) and for the whole set of rods (the data for standards were fitted to the power function). Each experiment and lipid analysis was run in duplicate. Residual acetate or lactate were quantified according to the UV-method of Bergmeyer (1974) using test-combination (Boehringer Mannheim).

\section{RESULTS}

\section{Bacterial growth and emulsifying activity}

The bacterial strains were not able to grow at sodium chloride $(\mathrm{NaCl})$ concentrations between 0 and $100 \mathrm{mM}$ and exhibited maximal growth at $\mathrm{NaCl}$ concentrations of $400 \mathrm{mM}$. They were thus characterized as marine bacteria according to the definition of Larsen (1986). Experiments were run at $\mathrm{NaCl}$ concentrations of $600 \mathrm{mM}$ in order to approach seawater conditions Generation times and degradation rates of the 4 strains grown on soluble and insoluble substrates are given in Table 1. Strain no. 8 was not able to grow on tetradecane as sole carbon and energy source. Generation times were longer on insoluble substrates than on soluble substrates. The bacterial strain Alcaligenes sp. PHY 9 exhibited better growth on hydrocarbon substrates than other strains did.

A microorganism's efficiency in producing a surfactant is determined by the ability of the culture medium to emulsify hydrophobic compounds. At the end of the exponential growth phase, emulsifying activity (EA) was therefore measured in the cell-free culture medium. EA's were 1.3- to 3-fold higher in culture medium of hydrocarbon-grown bacterial strains than in culture medium of acetate- or lactate-grown bacterial strains (Table 1). Nevertheless, this activity varied with hydrocarbon type. For example, the EA's of Alcaligenes sp. PHY 9 and Pseudomonas nautica 617 were higher on tetradecane substrate than on eicosane substrate 
Table 1. Characteristics of the 4 marine bacteria grown on acetate, lactate, tetradecane or eicosane substrates: degradation rate (degraded substrate \%), generation time (h) and emulsifying capacities of the culture medium (optical density). Enulsifying capacity was estimated by the optical density of the emulsion measured at $610 \mathrm{~nm}$ after $3 \mathrm{~h}$ stabilisation of the reaction system previously agitated (see 'Materials and Methods')

\begin{tabular}{|c|c|c|c|c|c|}
\hline $\begin{array}{l}\text { Bacterial } \\
\text { strain }\end{array}$ & $\begin{array}{l}\text { Substrate } \\
\left(\mathrm{g} \mathrm{l}^{-1}\right)\end{array}$ & & $\begin{array}{c}\text { Degradation } \\
\text { rate }(\%)\end{array}$ & $\begin{array}{l}\text { Generation } \\
\text { time (h) }\end{array}$ & $\begin{array}{l}\text { Optical } \\
\text { density }\end{array}$ \\
\hline Strain no. 8 & $\begin{array}{l}\text { Acetate } \\
\text { Eicosane }\end{array}$ & $\begin{array}{l}3 \\
1\end{array}$ & $\begin{array}{l}99 \\
56\end{array}$ & $\begin{array}{l}4.5 \\
22\end{array}$ & $\begin{array}{l}0.63 \\
1.15\end{array}$ \\
\hline Strain no. 17 & $\begin{array}{l}\text { Lactate } \\
\text { Tetradecane } \\
\text { Eicosane }\end{array}$ & $\begin{array}{l}2 \\
1 \\
1\end{array}$ & $\begin{array}{l}99 \\
99 \\
65\end{array}$ & $\begin{array}{l}2 \\
5 \\
8\end{array}$ & $\begin{array}{l}0.46 \\
1.5 \\
1.4\end{array}$ \\
\hline $\begin{array}{l}\text { Alcaligenes } \\
\text { sp. PHY } 9 \text { L } 86\end{array}$ & $\begin{array}{l}\text { Acetate } \\
\text { Tetradecane } \\
\text { Eicosane }\end{array}$ & $\begin{array}{l}2 \\
0.7 \\
1\end{array}$ & $\begin{array}{l}99 \\
98 \\
88\end{array}$ & $\begin{array}{l}4 \\
6 \\
6\end{array}$ & $\begin{array}{l}0.30 \\
0.80 \\
0.42\end{array}$ \\
\hline $\begin{array}{l}\text { Pseudomonas } \\
\text { nautica } 617\end{array}$ & $\begin{array}{l}\text { Acetate } \\
\text { Tetradecane } \\
\text { Eicosane }\end{array}$ & $\begin{array}{l}2 \\
1 \\
1\end{array}$ & $\begin{array}{l}99 \\
97 \\
40\end{array}$ & $\begin{array}{r}5 \\
6 \\
28\end{array}$ & $\begin{array}{l}0.56 \\
1.8 \\
0.8\end{array}$ \\
\hline
\end{tabular}

\section{Cellular and extracellular protein, total lipid and carbohydrate contents}

Protein yield estimated for all strains and substrates averaged $170.4 \mathrm{mg} 1^{-1}$ with a maximal value of $275.3 \mathrm{mg} \mathrm{l}^{-1}$ for Strain no. 17 grown on eicosane and a minimal value of $131.0 \mathrm{mg} \mathrm{l}^{-1}$ for Alcaligenes sp. PHY 9 grown on eicosane (Table 2). Compared to the supernatants, the biochemical composition of cells did not vary widely with substrate type and the relative proportions of protein, carbohydrate and lipid averaged 1:0.11:0.07 respectively. Nevertheless, lipid enrichment of cells occurred during growth on most insoluble substrates. Concentrations of extracellular protein were low averaging $3.65 \mathrm{mg} \mathrm{l}^{-1}$. Extracellular carbohydrate and lipid were found in all supernatants of bacterial cultures in concentrations ( $\mu \mathrm{g} \mathrm{mg}^{-1}$ protein) ranging from 16.7 to 289.18 and 3.46 to 188.59 respectively. Carbohydrate did not exhibit any clear pattern of change with substrate type. In contrast, lipids were 1.1- to 23-fold more concentrated in supernatant after cellular growth on insoluble substrates than in supernatant after cellular growth on soluble substrates. Maximum extracellular lipid release occurred for Strain no. 8 growing on eicosane and Pseudomonas nautica 617 growing on tetradecane.

\section{Cellular and extracellular lipid classes}

Cellular lipid classes (Table 3) were mainly phospholipids (average $81.69 \%$ ) and acetone soluble lipids

Table 2. Protein, carbohydrate and lipid contents in cells and supernatant from various marine bacterial strains grown on soluble or insoluble substrate

\begin{tabular}{|c|c|c|c|c|c|c|}
\hline \multirow{2}{*}{$\begin{array}{l}\text { Bacterial } \\
\text { strain }\end{array}$} & \multirow[t]{2}{*}{ Substrate } & \multicolumn{3}{|c|}{ Cells } & \multicolumn{2}{|c|}{ Supernatant } \\
\hline & & $\begin{array}{l}\text { Protein } \\
\left(\mathrm{mg} \mathrm{l}^{-1}\right)\end{array}$ & $\begin{array}{c}\text { Carbohydrate } \\
\text { (mg mg } \mathrm{mg}^{-1} \text { protein) }\end{array}$ & $\begin{array}{c}\text { Lipid } \\
\text { ( } \mu \mathrm{g} \mathrm{mg}^{-1} \text { protein) }\end{array}$ & $\begin{array}{c}\text { Carbohydrate } \\
\text { ( } \mu \mathrm{gg}^{-1} \text { protein) }\end{array}$ & $\begin{array}{c}\text { Lipid } \\
\text { ( } \mu \mathrm{g} \mathrm{mg}^{-1} \text { protein) }\end{array}$ \\
\hline Strain no. 8 & $\begin{array}{l}\text { Acetate } \\
\text { Eicosane }\end{array}$ & $\begin{array}{l}191.0 \\
136.8\end{array}$ & $\begin{array}{l}0.39 \\
0.32\end{array}$ & $\begin{array}{l}50.07 \\
77.35\end{array}$ & $\begin{array}{l}147.80 \\
289.18\end{array}$ & $\begin{array}{r}10.68 \\
188.59\end{array}$ \\
\hline Strain no. 17 & $\begin{array}{l}\text { Lactate } \\
\text { Tetradecane } \\
\text { Eicosane }\end{array}$ & $\begin{array}{l}220.5 \\
227.0 \\
275.3\end{array}$ & $\begin{array}{l}0.19 \\
0.12 \\
0.15\end{array}$ & $\begin{array}{r}44.08 \\
111.73 \\
31.99\end{array}$ & $\begin{array}{r}106.12 \\
17.44 \\
134.76\end{array}$ & $\begin{array}{r}7.98 \\
10.61 \\
56.55\end{array}$ \\
\hline $\begin{array}{l}\text { Alcaligenes } \\
\text { sp. PHY } 9 \text { L } 86\end{array}$ & $\begin{array}{l}\text { Acetate } \\
\text { Tetradecane } \\
\text { Eicosane }\end{array}$ & $\begin{array}{l}151.0 \\
156.4 \\
131.0\end{array}$ & $\begin{array}{l}0.02 \\
0.40 \\
0.13\end{array}$ & $\begin{array}{r}36.65 \\
44.95 \\
135.24\end{array}$ & $\begin{array}{l}70.72 \\
34.27 \\
55.34\end{array}$ & $\begin{array}{l}13.44 \\
50.17 \\
14.27\end{array}$ \\
\hline $\begin{array}{l}\text { Pseudomonas } \\
\text { nautica } 617\end{array}$ & $\begin{array}{l}\text { Acetate } \\
\text { Tetradecane } \\
\text { Eicosane }\end{array}$ & $\begin{array}{l}167.6 \\
214.3 \\
175.0\end{array}$ & $\begin{array}{l}0.12 \\
0.15 \\
0.13\end{array}$ & $\begin{array}{r}86.37 \\
86.20 \\
132.57\end{array}$ & $\begin{array}{l}16.70 \\
78.39 \\
31.42\end{array}$ & $\begin{array}{r}3.46 \\
80.26 \\
13.48\end{array}$ \\
\hline
\end{tabular}


Table 3. Composition of cellular lipids (\% of total lipids) of strains grown on acetate or lactate as soluble substrates and tetradecane and eicosane as insoluble substrates: phospholipids (PL), acetone mobile polar lipids including glycolipids and monoglycerides (AMPL), diglycerides (DG), sterols (ST), free alcohols (ALC), free fatty acids (FFA), triglycerides (TG), methyl esters and ketone ( $\mathrm{ME}+\mathrm{KE}$ ), wax esters and sterol esters (WE+SE), unknown compounds with intermediate retention time (UNK)

\begin{tabular}{|c|c|c|c|c|c|c|c|c|c|c|c|}
\hline $\begin{array}{l}\text { Bacterial } \\
\text { strain }\end{array}$ & Substrate & PL & AMPL & $D G$ & $\mathrm{sT}$ & $\begin{array}{c}\text { ALC } \\
(\%)\end{array}$ & FFA & TG & $\mathrm{ME}+\mathrm{KE}$ & $W E+S E$ & UNK \\
\hline Strain no. 8 & $\begin{array}{l}\text { Acetate } \\
\text { Eicosane }\end{array}$ & $\begin{array}{l}91.47 \\
72.45\end{array}$ & 10.6 & $\begin{array}{l}- \\
-\end{array}$ & - & - & 5.14 & $\begin{array}{c}6.67 \\
-\end{array}$ & - & $\begin{array}{l}- \\
7.38\end{array}$ & $\begin{array}{l}1.85 \\
4.42\end{array}$ \\
\hline Strain no. 17 & $\begin{array}{l}\text { Lactate } \\
\text { Tetradecane } \\
\text { Eicosane }\end{array}$ & $\begin{array}{l}87.86 \\
51.27 \\
80.40\end{array}$ & $\begin{array}{r}- \\
2.79 \\
5.50\end{array}$ & $\begin{array}{c}1.47 \\
- \\
-\end{array}$ & $\begin{array}{l}- \\
- \\
-\end{array}$ & $\begin{array}{c}- \\
1.27 \\
-\end{array}$ & $\begin{array}{l}6.12 \\
3.33 \\
6.09\end{array}$ & $\begin{array}{r}2.63 \\
17.72 \\
1.28\end{array}$ & $\begin{array}{c}- \\
1.87 \\
--\end{array}$ & $\begin{array}{c}- \\
21.73 \\
4.93\end{array}$ & $\begin{array}{c}1.97 \\
- \\
1.78\end{array}$ \\
\hline $\begin{array}{l}\text { Alcaligenes } \\
\text { sp. PHY } 9\end{array}$ & $\begin{array}{l}\text { Acetate } \\
\text { Tetradecane } \\
\text { Eisocane }\end{array}$ & $\begin{array}{l}81.86 \\
95.66 \\
85.16\end{array}$ & $\begin{array}{l}2.02 \\
0.11 \\
1.70\end{array}$ & $\begin{array}{c}- \\
- \\
1.00\end{array}$ & $\begin{array}{c}1.52 \\
- \\
-\end{array}$ & $\begin{array}{c}7.6 \\
- \\
0.75\end{array}$ & $\begin{array}{c}7.14 \\
- \\
2.01\end{array}$ & $\begin{array}{l}- \\
- \\
6.55\end{array}$ & $\begin{array}{l}- \\
- \\
-\end{array}$ & $\begin{array}{l}- \\
4.22 \\
2.81\end{array}$ & $\begin{array}{l}- \\
- \\
-\end{array}$ \\
\hline $\begin{array}{l}\text { Pseudomonas } \\
\text { nautica } 617\end{array}$ & $\begin{array}{l}\text { Acetate } \\
\text { Tetradecane } \\
\text { Eicosame }\end{array}$ & $\begin{array}{l}91.95 \\
73.15 \\
87.55\end{array}$ & $\begin{array}{l}1.57 \\
1.81 \\
1.91\end{array}$ & $\begin{array}{c}- \\
0.47 \\
-\end{array}$ & $\begin{array}{c}- \\
0.72 \\
-\end{array}$ & $\begin{array}{c}- \\
- \\
0.75\end{array}$ & $\begin{array}{l}- \\
- \\
-\end{array}$ & $\begin{array}{l}1.43 \\
4.46 \\
0.67\end{array}$ & $\begin{array}{l}- \\
- \\
-\end{array}$ & $\begin{array}{l}- \\
6.50 \\
3.25\end{array}$ & $\begin{array}{l}- \\
- \\
-\end{array}$ \\
\hline
\end{tabular}

(average $3.1 \%$ ) for polar lipids and wax esters (average $7.26 \%$ ) and triglycerides (average $5.17 \%$ ) for neutral lipids. Variations in total phospholipid concentrations in cells did not correlate with change in substrate type. In contrast, concentrations of acetone mobile polar lipids were higher in cells grown on insoluble substrate than in cells grown on soluble substrates for Pseudomonas nautica and Strains no. 8 and no. 17. Strain 17 exhibited high cellular concentrations of storage lipids such as triglycerides (17.7\%) and wax esters $(21.7 \%)$ after growth on tetradecane.

Lipid compositions of extracellular material were different from lipid composition of endocellular material (Table 4). Extracellular lipids were characterized by a large heterogeneity. For example, the phospholipids to acetone mobile polar lipids (PL/ AMPL) ratios were $0.95,0.80,3.68$ and 6.20 in supernatants of Strain no. 8, Strain no. 17, Alcaligenes sp. PHY 9 and pseudomonas nautica respectively, after growth on eicosane. Moreover, free fatty acids were major compounds in Alcaligenes sp. PHY 9 supernatants, while they were only slightly concentrated in supernatants of other strains.

Comparison between extracellular production on soluble substrate and insoluble substrate show that polar lipids production was enhanced in supernatants of cultures grown on insoluble compounds (Fig. 1). Maximal enhancement $(\times 20)$ occurred for phospholipids. Concentrations of neutral lipids varied with strains and substrate characteristics. Highest concentrations were related to tetradecane substrate.

\section{DISCUSSION}

The 4 marine bacterial strains tested in this study produced organic compounds in their culture medium when grown on either soluble or insoluble substrates.

Table 4. Composition of extracellular lipids (\%) from acetate, lactate or alkane-grown cultures. (For abbreviations see Table 3)

\begin{tabular}{|c|c|c|c|c|c|c|c|c|c|}
\hline $\begin{array}{l}\text { Bacterial } \\
\text { strain }\end{array}$ & Substrate & PL & AMPL & $\mathrm{DG}$ & TG & FFA & $\mathrm{ME}+\mathrm{KE}$ & $W E+S E$ & UNK \\
\hline Strain no. 8 & $\begin{array}{l}\text { Acetate } \\
\text { Eicosane }\end{array}$ & $\begin{array}{l}43.1 \\
48.7\end{array}$ & $\begin{array}{l}56.8 \\
51.2\end{array}$ & $\begin{array}{l}- \\
-\end{array}$ & $\begin{array}{l}- \\
-\end{array}$ & $\begin{array}{l}- \\
-\end{array}$ & $\begin{array}{l}- \\
-\end{array}$ & - & $\begin{array}{l}- \\
-\end{array}$ \\
\hline Strain no. 17 & $\begin{array}{l}\text { Lactate } \\
\text { Tetradecane } \\
\text { Eicosane }\end{array}$ & $\begin{array}{l}29.5 \\
61.3 \\
43.0\end{array}$ & $\begin{array}{l}16.4 \\
11.0 \\
53.4\end{array}$ & $\begin{array}{c}- \\
2.0 \\
-\end{array}$ & $\begin{array}{c}15.3 \\
4.1 \\
3.53\end{array}$ & $\begin{array}{l}- \\
8.1 \\
-\end{array}$ & $\begin{array}{l}- \\
- \\
-\end{array}$ & $\begin{array}{c}- \\
10.2 \\
-\end{array}$ & $\begin{array}{c}24.4 \\
3.3 \\
-\end{array}$ \\
\hline $\begin{array}{l}\text { Alcaligenes } \\
\text { sp. PHY } 9\end{array}$ & $\begin{array}{l}\text { Acetate } \\
\text { Tetradecane } \\
\text { Eisocane }\end{array}$ & $\begin{array}{l}46.8 \\
11.4 \\
74.8\end{array}$ & $\begin{array}{r}\text { Tr. } \\
3.8 \\
20.3\end{array}$ & $\begin{array}{c}1.9 \\
- \\
-\end{array}$ & $\begin{array}{c}0.9 \\
8.0 \\
-\end{array}$ & $\begin{array}{l}51.7 \\
73.2 \\
\operatorname{Tr}\end{array}$ & $\begin{array}{l}0.9 \\
- \\
-\end{array}$ & $\begin{array}{l}- \\
3.5 \\
4.8\end{array}$ & $\begin{array}{l}- \\
- \\
-\end{array}$ \\
\hline $\begin{array}{l}\text { Pseudomonas } \\
\text { nautica } 617\end{array}$ & $\begin{array}{l}\text { Acetate } \\
\text { Tetradecane } \\
\text { Eicosane }\end{array}$ & $\begin{array}{l}82.7 \\
70.2 \\
48.5\end{array}$ & $\begin{array}{r}17.2 \\
6.4 \\
7.8\end{array}$ & $\begin{array}{l}- \\
- \\
-\end{array}$ & $\begin{array}{l}- \\
1.5 \\
-\end{array}$ & $\begin{array}{r}- \\
5.2 \\
17.7\end{array}$ & $\begin{array}{l}- \\
- \\
-\end{array}$ & $\begin{array}{c}- \\
15.1 \\
25.9\end{array}$ & $\begin{array}{l}- \\
1.3 \\
-\end{array}$ \\
\hline
\end{tabular}


(a)
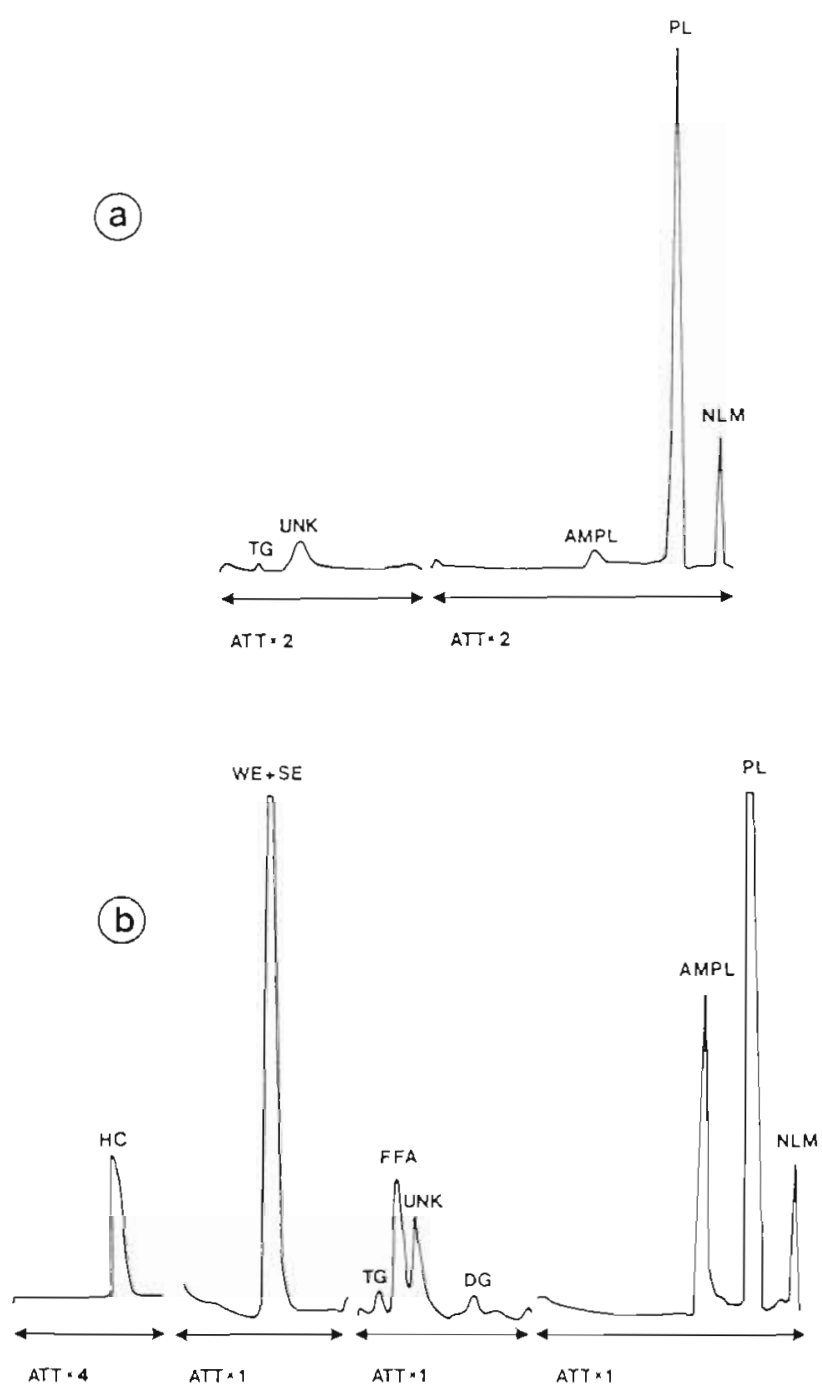

Fig. 1. Extracellular lipid chromatograms from Strain no. 17 grown on (a) soluble substrate (lactate, 2 partial scans) and on (b) insoluble substrate (tetradecane, 4 partial scans). Att: attenuation. For abbreviations see Table 3

These compounds were found to provide the medium with surface active properties according to Gutnick \& Minas (1987) who assume that all living cells produce amphipatic molecules. Carbohydrates and lipids were the main products whereas proteins were poorly excreted. In spite of the high extracellular release of carbohydrates, the adaptation of the marine strains to insoluble substrates was characterized by lipid excretions. The heterogeneity of lipid excretions, already described in the literature (reviewed by Rosenberg 1986 and Cooper 1986) must be emphasized (for example, free fatty acid production was much higher for Alcaligenes sp. PHY 9 than for other strains and within this strain, the amount of free fatty acid varied with substrate type). These excretions covaried well with the enhancement of emulsifying activity in super- natants and occurred in the same way, whatever the insoluble substrate was (i.e. under liquid [tetradecane] or solid form [eicosane]).

Several aspects of bacterial excretion are well documented in the literature, such as production of exoenzymes (Hoppe et al. 1988), production of exopolymers involved in microbial aggregation reaction in natural ecosystems (reviewed by Marshall 1987) and production of molecules with potential industrial applications (reviewed by Gutnick \& Minas 1987). Nevertheless, there is little data which can lead to an evaluation of dissolved organic compound inputs through bacterial activity in the marine environment. Furthermore, as recent studies (Azam et al. 1983, Fasham 1984, Sherr et al. 1988) have pointed out, the major role of bacteria as a biomass component in the aquatic environments - excretions of dissolved organics resulting from the biochemical adaptation of bacteria to their direct environment - must be taken into account when quantifying the flow of organic matter through the bacterial compartment, in areas where bacterial biomass actively develops. From our data, it can be concluded that in culture conditions, $1 \mathrm{mg}$ bacterial protein releases 16 to $289 \mu \mathrm{g}$ carbohydrates and 8 to $188 \mu \mathrm{g}$ lipids in the extracellular liquid medium. According to the recent estimate of the bacterial protein to cell carbon ratio (0.54) proposed by Simon \& Azam (1989), these excretions represented 8.6 to $156.2 \mu \mathrm{g}$ and 4.3 to $101.6 \mu \mathrm{g}$ per $\mathrm{mg}$ of bacterial carbon, for carbohydrates and lipids respectively. Maximum inputs of dissolved lipids occur when bacterial proteins are obtained from an insoluble carbon source. Considering that most interfaces accumulate active bacterial biomass and insoluble compounds (Crow et al. 1976, Marty \& Saliot 1976, Burns \& Saliot 1986, Williams et al. 1986, Zutic \& Legovic 1987) dissolved lipid inputs through bacterial activity could be effective here. Consequences on the physico-chemical characteristics at air/sea interface could be considerable as only $0.05 \%$ wt solutes are required to induce a change in microlayer viscosity (Carlson 1987).

Acknowledgements. This work was carried out within the framework of the Groupement d'Intérêt Scientifique, 'Cycles Biogeochimiques - Devenir de la Matière Organique en Zone Littorale'. The authors thank the Centre National de la Recherche Scientifique, the 'Programme Interdisciplinaire de Recherche sur l'environnement', and the 'Société Nationale Elf Aquitaine' for financial support.

\section{LITERATURE CITED}

Azam, F., Fenchel, T., Field, J. G., Gray, J. S., Meyer-Reil, L.-A., Thingstad, F. (1983). The ecological role of water-column microbes in the sea. Mar Ecol. Prog. Ser 10:257-263

Bergmeyer, H. U. (ed.) (1974). Methods of enzymatic analysis. 
Verlag Chemie, Weinheim, and Academic Press, New York, Vol. 2, p. 1475-1578

Bligh, E. G., Dyer, W. J. (1959). A rapid method of total lipid extraction and purification. Can. J. Biochem. Physiol. 37: $911-917$

Burns, K. A. Saliot, A. (1986). Petroleum hydrocarbons in the Mediterranean Sea: a mass balance. Mar Chem. 20: $141-157$

Carlson, D. J. (1987). Viscosity of sea-surface slicks. Nature, Lond. 329: 823-825

Carlucci, A. F., Craven, D. B., Henrichs, S. M. (1985). Surface film microheterotrophs: amino-acid metabolism and solar radiation effects on their activities. Mar. Biol. 85: 13-22

Cooper, D. G. (1986). Biosurfactants. Microbiol. Sci. 3: 145-147

Crow, S. A., Cook, W. L., Ahearn, D. G., Bourquin, A. W. (1976). Microbial population in coastal surface slicks. In: Sharpley, J. M., Kaplan, A. M. (eds.) Proc. Third International Biodegradation Symposium. Applied Science Publishers, London, p. 93-98

Delmas, R. P., Parrish, C. C., Ackman, R. G. (1984). Determination of lipid class concentrations in sea water by thinlayer chromatography with flame ionization detection. Analyt. Chem. 56: 1272-1277

Dubois, M., Gilles, K. A., Hamilton, J. K., Rebers, P. A., Smith, F. (1956). Colorimetric method for determination of sugars and related substances. Analyt. Chem. 28: 350-356

Fasham, M. J. R. (1984). Flow analysis of materials in the marine euphotic zone. In: Ulanowicz, R. E., Platt, T (eds.) Ecosystem theory for biological oceanography. Can. Bull. Fish. Aquat. Sci. 213: 139-162

Fehon, W. C., Oliver, J. D. (1979). Taxonomy and distribution of surface microlayer bacteria from two estuarine sites. Estuaries 2: 194-197

Goutx, M., Mutaftshief, S., Bertrand, J. C. (1987). Lipid and exopolysaccharide production during the hydrocarbon growth of a marine bacterium from the sea surface. Mar Ecol. Prog. Ser. 40: 259-265

Guerra-Santos, L., Käppeli, O., Fiechter, A. (1984). Pseudomonas aeruginosa biosurfactants production in continuous culture with glucose as carbon source. Appl. envirl Microbiol. 48: 301-305

Gutnick, D., Minas, W. (1987). Perspectives on microbial surfactants. K. S. Dodgson Memorial Symposium Trans. biochem. Soc. 15: 22S-35S

Hô, R., Marty, J. C., Saliot, A. (1982). Hydrocarbons in the western Mediterranean Sea, 1981. Int. J. environ. analyt. Chem. 12: 81-98

Hoppe, H. G., Kim, S. J., Gocke, K. (1988). Microbial decomposition in aquatic environments: combined process of extracellular enzyme activity and substrate uptake. Appl. envirl Microbiol. 54: 784-790

Jullien, D., Cauwet, G., Marty, J. C., Saliot, A. (1982), La matière organique particulaire de la microcouche de surface des eaux de mer, bilan, accumulation et complexation. C. r. Acad Sci, Paris 295: 367-370

This article was presented by Dr A. Bianchi, Marseille, France
Krieg, N. R., Holt, J. G. (eds.) (1984). Bergeys's manual of determinative bacteriology, 9th edn., Vol. 1. Williams and Wilkins, Baltimore

Larsen, H. (1986). Halophilic and halotolerant microorganisms. An overview and historical perspective. FEMS Microbiol. Rev. 39: 3-7

Lowry, O. H. Rosebrough, N. J., Farr, A. L., Randall, R. J, (1951). Protein measurement with the Folin phenol reagent. J. biol. Chem. 95: 2102-2107

Marty, J. C., Saliot, A. (1976). Hydrocarbons (normal alkanes) in the surface microlayer of sea water Deep Sea Res. 23: $863-873$

Marshall, K. C. (1987). Theory and practice in bacterial adhesion processes. In: Megusar, F., Gantar, M. (eds.) Perspectives in microbial ecology. Proc. Fourth International Symposium on Microbial Ecology. Slovene Society for Microbiology Publishers, Ljubljana, p. 112-117

Rambeloarisoa, E., Rontani, J F., Giusti, G., Duvnjak, Z., Bertrand, J. C. (1984). Degradation of crude oil by a mixed population of bacteria isolated from sea-surface foams. Mar. Biol. 83: 69-81

Reiling, H. E., Thanei-Wyss, U., Guerra-Santos, L. H., Hirt, R., Käppeli, O., Fiechter, A. (1986). Pilot plant production of Rhamnolipid biosurfactant by Pseudomonas aeruginosa. Appl. envirl Microbiol. 51: 985-989

Romano, J. C. (1988). Les populations bactériennes à I'interface air-mer. In. Bianchi, M., Marty, D., Bertrand, J. C., Caumette, P., Gauthier, M. (eds.) Micro-organismes dans les ecosystèmes océaniques. Masson Publishers, Paris, p. $153-184$

Rosenberg, E. (1986). Microbial surfactants. CRC Crit. Rev. Biotechnol. 3: 109-132

Roy, P. R., Singh, H. D., Bhagat, S. D., Baruah, J. N. (1979). Characterization of hydrocarbon emulsification and solubilization occurring during the growth of Endomycopsis Lipolytica on hydrocarbon. Biotechnol. Bioeng. 21: 955-974

Sherr, B. F., Sherr, E. B., Rassoulzadegan, F. (1988). Rates of digestion of bacteria by marine phagotrophic protozoa: temperature dependence. Appl. envirl Microbiol. 54: $1091-1095$

Simon, M., Azam, F. (1989). Protein content and protein synthesis rates of planktonic marine bacteria. Mar. Ecol. Prog. Ser 51: 201-213

Williams, P. M., Carlucci, A. F., Henrichs, S. M., Van Vleet, E S., Horrigan, S. G., Reid, F. M. H., Robertson, K. J. (1986). Chemical and microbiological studies of sea-surface films in the Southern Gulf of California and off the West Coast of Baja California, Mar. Chem. 19: 17-98

Zajic, J. E., Mahomedy, A. Y (1984). Biosurfactants: intermediates in the biosynthesis of amphipatic molecules in microbes. In: Atlas, R. M. (ed.) Petroleum microbiology. MacMillan Company Publishers, New York, p. 221-297

Zutic, V., Legovic T (1987). A film of organic matter at the fresh-water/sea-water interface of an estuary. Nature, Lond. 328: 612-614

Manuscript first received: July 6,1989

Revised version accepted: January 9, 1990 